PROGRAM CONTACT: SERGEI ROMASHKAN (301) 435-3047

romashks@nia.nih.gov

Principal Investigators (Listed Alphabetically):

(Privileged Communication)
Release Date:

$12 / 09 / 2016$

\title{
KERR, JACQUELINE
}

LACROIX, ANDREA Z. (Contact)

Applicant Organization: UNIVERSITY OF CALIFORNIA SAN DIEGO

Review Group: ZAG1 ZIJ-7 (J1)

National Institute on Aging Special Emphasis Panel

Second Stage P01 Review

Meeting Date: 11/21/2016

Council: JAN 2017

Requested Start: 04/01/2017

Project Title: Sedentary Behaviour Interrupted: Acute, medium and long-term effects on biomarkers of healthy aging, physical function and mortality

SRG Action: Impact Score:20

Next Steps: Visit http://grants.nih.gov/grants/next_steps.htm

Human Subjects: 30 -Human subjects involved - Certified, no SRG concerns

Animal Subjects: 10-No live vertebrate animals involved for competing appl.

Gender: 2A-Only women, scientifically acceptable

Minority: 1A-Minorities and non-minorities, scientifically acceptable

Children: 3A-No children included, scientifically acceptable

Clinical Research - not NIH-defined Phase III Trial

\begin{tabular}{c} 
Project \\
Year \\
1 \\
2 \\
3 \\
4 \\
5 \\
\hline TOTAL
\end{tabular}

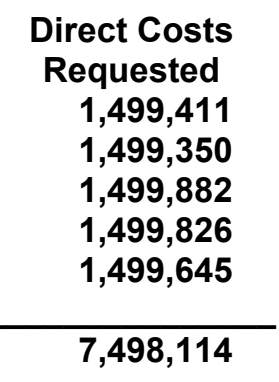

Estimated

Total Cost

$2,328,592$

$2,328,498$

$2,329,324$

$2,329,237$

$2,328,956$

$11,644,606$

ADMINISTRATIVE BUDGET NOTE: The budget shown is the requested budget and has not been adjusted to reflect any recommendations made by reviewers. If an award is planned, the costs will be calculated by Institute grants management staff based on the recommendations outlined below in the COMMITTEE BUDGET RECOMMENDATIONS section. 


\section{PROJECT 2: SEDENTARY BEHAVIOR INTERRUPTED: A RANDOMIZED TRIAL OF 3-MONTH EFFECTS OF BIOMARKERS OF HEALTHY AGING AND PHYSICAL FUNCTIONING IN THE REAL WORLD; Dr. Jacqueline Kerr, Project Leader (PL)}

DESCRIPTION (provided by applicant): Project 2 of the Sedentary Time and Aging Research (STAR) Program will investigate how 3 month changes in standing time, brief sit-to-stand transitions and physical activity (PA) breaks, will impact biomarkers of healthy aging, and physical, emotional and cognitive functioning compared to healthy living attention controls. This 4-arm randomized controlled trial $(\mathrm{RCT})$ will occur in the 'real world' with postmenopausal women $(\mathrm{N}=592)$ who are not physically active, do not stand up frequently and spend at least 8 hours sitting per day, i.e. most older adults. The daily behavior targets in each condition of Project 2 (increase standing by 2 hours, increase sit-to-stand transitions by 30 per day, \& increase PA breaks by 12) reflect the treatment conditions explored in Project 1. To date, there have been no RCT studies with health outcomes in older adults. Our multiple pilot studies, however, demonstrate the feasibility and acceptability of delivering intervention materials (including standing desks, trackers \& ActivPAL feedback) to older adults and evaluating behavior change objectively with thigh-worn inclinometers. The interventions significantly reduced sitting time (up to 2 hours a day) and significantly increased sit-to-stand transitions (up to 40 per day). Increases in PA were minimal in the standing conditions, compared to our PA focused RCT in 307 older adults which increased short PA bouts. One pre-post pilot found that reductions in sitting time were significantly related to improved gait speed and decreased depressive symptoms. Project 2 will assess the impact of the 3 interventions to interrupt sitting compared to the attention control condition at 6 and 12 weeks. We will recruit 592 overweight, sedentary, postmenopausal women who will be randomized to one of the 4 conditions. We will employ tools such as standing desks, wrist-worn device alerts and conditionspecific, tailored ActivPAL feedback. The primary outcomes are glucose regulation and blood pressure. Secondary outcomes include mitochondrial functioning (measured by muscle mitochondrial respiratory capacity), and physical, emotional and cognitive functioning. Exploratory outcomes include psychosocial and environmental mediators and moderators of behavior change. We will also explore the moderating effect of age on the intervention outcomes. Project 2 compliments the other projects by assessing 3 month intermediary outcomes. Project 2 will help validate the novel computational algorithms optimized in Project 1 and applied to Project 3. In addition, the Biostatistics Core will investigate the response patterns in Projects 1 and 3 and map them to Project 2. Project 2 will strengthen the public health evidence of how to interrupt sitting time in older adults, provide specific information on interrupting sitting as an alternative to longer PA bouts, and explore a range of targeted outcomes related to healthy aging.

\section{CRITIQUE 1:}

Significance: 2

Investigator(s): 1

Innovation: 1

Approach: 4

Environment: 1

\section{Overall Impact:}

This updated and revised Project 2 application aims to compare three interventions (increased standing, increased sit-to-stand transitions, and increased PA bouts) to disrupt sitting with a control group on markers of glucose regulation and blood pressure. As secondary aims, the investigators will assess whether these interventions impact muscle mitochondrial capacity; physical, emotional and cognitive outcomes. Finally, the effect of age, psychosocial and environmental factors on these relationships will be examined and the outcomes will be compared between interventions. This is an application from an experienced investigative team with a successful record of publications and funding 
in the area of physical activity and sedentary behavior. The PL, Co-ls and consultants are all well positioned to successfully complete this project and disseminate the results. The research question within this application has important clinical, scientific and practical significance. The investigators were responsive to the previous review. However, changes to the physical activity intervention and a lack of detailed descriptions of the interventions has diminished the reviewer's enthusiasm for this application.

\section{Significance:}

\section{Strengths}

- Interventions that focus on interrupting or decreasing time spent in sedentary behaviors in this population may show a clinical benefit.

- The population of focus in this application would likely benefit greatly from reductions in sitting and increases in movement.

- Comparing changes in behaviors and biomarkers in response to interventions that aim to reduce sitting, increase disruptions to sedentary behavior, and increase physical activity will be highly informative to future interventions.

- Few studies have examined the impact of disrupting sitting time outside of the laboratory, therefore the results of this project will provide information on the efficacy of these interventions as well as on the outcomes listed.

\section{Weaknesses}

- The PA intervention changed from increasing PA by $30 \mathrm{~min} /$ day to taking 12 extra 2-5 min PA breaks per day. This is still a break to (potentially) sedentary behavior and may not be distinct enough from the other intervention conditions.

\section{Investigator(s):}

Strengths

- The PL is a mid-career investigator with a strong publication and funding history in this area of inquiry.

- The team has successfully worked together in the past and continue to work together on other projects.

- There appears to be sufficient and qualified personnel to carry out the research project (Health

\section{Weaknesses} Educator, Project Coordinator, Recruiter, etc.).

- None noted.

\section{Innovation:}

\section{Strengths}

- This Project will be the first RCT to examine and compare the effects of three interventions to disrupt and/or reduce sedentary behavior in post-menopausal women.

- There is a lack of RCTs examining interruptions to sitting.

- This project will be the first to examine the impact of using standing desks outside of the workplace or school to reduce sitting behavior.

- This project will compare three interventions to disrupt sitting- one with standing, one with increased sit-to-stand transitions, and one with physical activity.

- Comparing the effect of these interventions on muscle mitochondrial function is novel.

\section{Weaknesses}

- None noted.

\section{Approach:}

\section{Strengths}

- The use of valid and reliable measures of SB and PA is a strength. 
- The application of RCT is a strong design, with a strong rationale supporting separation of standing and sit-to-stand transitions as separate interventions. This design and the outcome of this study will give researchers and clinicians an indication the effectiveness of sitting interruption interventions. Further, comparing 2 sedentary interventions to a PA group and a control group may allow the investigators to answer many questions about the efficacy of the standing interventions vs. PA interventions, pending distinctness of the interventions.

- The researchers have tried to isolate each intervention behavior - standing, transitions from sitting to standing, and PA.

- The use of the CTRI, the new AHA Center, and the numerous other Center connections will strengthen the application.

- The control group intervention is strong, with a clear indication of information that will be delivered.

- The inclusion/exclusion criteria pertaining to sitting, sit-to-stand transitions and physical activity are strong and will result in a study population that is highly likely to benefit from the intervention.

- The screening process is well described and thorough.

Weaknesses

- The descriptions of the interventions are lacking. It is not clear what will be asked of the participants in the intervention arms. Are the participants given suggestions on what to do to once they stand up? Will they be restricted to standing only? What types of PA will be recommended? Further, is it not clear how distinct the interventions will be from each other, once the participants start carrying out the interventions. The potential overlap in the interventions will result in an inability to decipher the unique effects on the outcomes of interest.

- The rationale for the 2-5 min PA breaks is not clear. This PA recommendation is not in line with the PA recommendations.

- The dose of activity in each of these interventions is not equated, which will make it difficult to compare the outcome to standing, sit-to-stand transitions, to PA.

- The validation of machine learning algorithms is not well integrated into the application.

\section{Environment:}

\section{Strengths}

- The University, the CTRI, and the Centers are well- equipped and supportive of the successful completion of this application.

\section{Weaknesses}

- Outstanding.

- None noted.

Protections for Human Subjects:

Acceptable risks and adequate protections.

Data and Safety Monitoring Plan:

Acceptable.

- While a DSMP is not needed, it provides and additional layer of protection for the research participants.

Inclusion of Women, Minorities and Children:

- Sex/Gender: Distribution justified scientifically.

- Race/Ethnicity: Distribution justified scientifically.

- For NIH-Defined Phase III trials, Plans for valid design and analysis: Not applicable.

- Inclusion/Exclusion of Children under 18: Excluding ages <18; justified scientifically. 
- The inclusion of women only is justified in the application.

\section{Resubmission:}

- The investigators address most of the comments provided by the reviewers. However, one arm of the intervention was changed from a 30-minute PA intervention to 12, 2-5 minute PA breaks. The reviewer is not convinced this will be distinct enough from the sit-to-stand intervention.

- The interventions are not well described. It is not clear what the participants will be told to do in each of the interventions. For instance, if they stand up, can they move to go get a drink of water?

- With the removal of the biomarkers core, there were 4 additional personnel added to this Project, which will strengthen the quality and dissemination of the project.

\section{Budget and Period of Support:}

Recommend as Requested.

\section{CRITIQUE 2:}

Significance: 1

Investigator(s): 1

Innovation: 2

Approach: 5

Environment: 1

\section{Significance:}

\section{Strengths}

- Sedentary behavior is important risk factor for older adults and there is a need to understand lifestyle approaches to avert these effects.

- Results have the potential to inform lifestyle approaches to reduce negative health effects of

Weakness sedentary behavior.

- None noted.

\section{Investigators:}

\section{Strengths}

- The investigative team is outstanding and well qualified to conduct the proposed trial.

\section{Weakness}

- None noted.

\section{Innovation:}

\section{Strengths}

- This will be the first RCT to focus on changing sedentary behavior in overweight postmenopausal women.

- Multiple approaches will be assessed.

- Concurrent measures of glycemic control and endothelial function outcomes.

\section{Weaknesses}

- Although post-menopausal women have not been studied before in a randomized trial, it is not abundantly clear why other older adults at risk are not included.

\section{Approach:}

\section{Strengths}


- Use of mobile tools to track sitting interruptions in real time and also summarized at the daily/weekly level.

- Feasibility supported by large-scale pilot trials.

Weaknesses

- The rationale for the PA condition is confusing. It is stated that the 2-5 min breaks were selected to be in line with the PA guidelines. However, the PA guidelines are focused on accumulation of moderate intensity activity in bouts of $10 \mathrm{~min}$ or more. Thus, the investigators related to the accumulation of moderate to vigorous intensity activity of 30 min over the course of a day. However, the bouts are referred to a "light" PA bouts which would not be consistent or related to PA guidelines. The intensity of the PA breaks is not described. If light intensity, then the recommended PA breaks are not consistent with current PA guidelines.

- Given that the total amount of time that participants take break from sedentary behavior vary across conditions, the findings of the proposed study may be difficult to interpret since it would not be clear if changes were due to a dose effect or type of activity effect.

- Power is limited to detect differences across intervention conditions. This is a significant weakness given the potential importance of this question for health recommendations for older adults.

\section{Environment:}

\section{Strengths:}

- The Environment to conduct the planned study is outstanding.

\section{Weaknesses}

- None noted.

\section{Protections for Human Subjects:}

Acceptable Risks and/or Adequate Protections.

- No concerns.

\section{Data and Safety Monitoring Plan:}

- Acceptable.

\section{Inclusion of Women, Minorities and Children:}

- Sex/Gender: Distribution justified scientifically.

- Race/Ethnicity: Distribution justified scientifically.

- For NIH-Defined Phase III trials, Plans for valid design and analysis: Not applicable.

- Inclusion/Exclusion of Children under 18: Excluding ages <18; justified scientifically.

\section{Vertebrate Animals:}

Not Applicable (No Vertebrate Animals).

\section{Resubmission:}

- Investigators were very responsive to recommendations from previous submission.

\section{Budget and Period of Support:}

Recommend as Requested.

\section{CRITIQUE 3:}

Significance: 2

Investigator(s): 1

Innovation: 1 


\section{Approach: 2}

Environment: 1

\section{Overall Impact:}

The outcomes of this Project, if achieved, have important clinical and practical significance to the field of health promotion and PA. This is a well-written application from experienced team who have demonstrated by previous work that they are likely to achieve this ambitious project. Project 2 is innovative, comparing 3 interventions to attention/education controls. This Project will have multiple outcomes, from those demonstrating mechanisms of improvement in health from objective measures (NIRS, glucose regulation, BP) to self-reported physical, psychosocial, cognitive, and other exploratory outcomes. Enthusiasm for this project is high and is likely to have a substantial impact on the science of SB and PA and how they may improve health. Weaknesses are focused primarily on the approach. Main concerns include attrition of subjects, overlap of the conditions of the 3 arms, compliance with the intervention conditions by subjects.

\section{Significance:}

\section{Strengths}

- Developing effective interventions for older women, other than PA, that will improve health (glucose regulation, BP, etc.) is important to improve methods for lifestyle counseling.

- There is a need to study older adults who frequently have metabolic impairments and who could likely show maximal benefit from interrupting SB especially since many older adults do not regularly exercise due to perceived or real barriers.

- Improves scientific evidence of methods of interrupting SB and which method would be superior in terms of important metabolic outcomes.

- If this Project is successful and outcomes achieved, it is likely to have great impact on the field of health promotion \& disease prevention.

- Improved rational for scientific evidence of outcomes

\section{Weaknesses}

- Not provided.

\section{Investigator(s):}

\section{Strengths}

- Successful team, demonstrated outcomes, highly qualified to conduct this ambitious program.

- Preliminary data and pilot studies performed provide confidence in ability to complete ambitious project.

\section{Weaknesses}

- None noted.

\section{Innovation:}

\section{Strengths}

- Comparing 3 treatment conditions of reducing SB and comparing metabolic outcomes of each group is highly innovative and not accomplished to date.

- Adding mitochondrial measures -NIRS- helps determine mechanisms of action of reducing SB and is innovative.

- Whether emotional and functional outcomes will improve by interrupting SB using different

\section{Weaknesses} methods is an innovative question, yet particularly salient for older adults.

- Interventions methods/components of changing SB behaviors not highly innovative and may not be pragmatic.

\section{Approach:}




\section{Strengths}

- 4 arm comparisons.

- Objective measures and self-reported measures for primary, secondary and exploring mediators and moderators.

- Shorter outcome time in resubmission to test interventions will lesson attrition and improve probability of success.

- Measures of adherence for each condition, important to measure satisfaction with protocol to inform future studies.

- Improved clarity of inclusion/exclusion criteria (and rationale for), measures of PA/SB with both ActivPAL and Actigraph.

- Investigators very responsive to suggestions from previous submission \& improved methods.

- Biostatistics support excellent.

\section{Weaknesses}

- Intervention components are very ambitious. Not sure if older women will accept the burden of intervention components (many visits to medical center, multiple phone calls, blood draws; packaged dinners, nothing by mouth status); not sure they can accomplish the requirements of each arm, thus limiting variability in outcomes.

- Remained concerned with recruitment and retention of participants and $10 \%$ attrition rate is over ambitious (most PA trials at least 20\%).

- There is a concern about experimental condition overlap; e.g. standing breaks and brief sit to stand transitions are very similar and subjects may not perform correctly, e.g. PA short breaks may be taken instead of just standing in place.

- Intervention not pragmatic, difficult to enact \& would be difficult to replicate in clinical practice because each intervention is testing multiple components that have a menu of choices/different components for each woman to perform. Will each arm be representing the same treatment?

- 20 minute MVPA arm replaced with PA breaks; rational for the latter is lacking, more important to include one arm with the current recommendation (20 min MVPA).

- Motivational interviewing is mentioned as a behavioral strategy in intervention, but components not supported by Table 1, maybe just motivational components and self-efficacy.

\section{Environment: \\ Strengths}

- Superior research environment.

\section{Weaknesses}

- None noted.

\section{Protections for Human Subjects:}

Acceptable Risks and/or Adequate Protections.

\section{Data and Safety Monitoring Plan:}

Acceptable.

\section{Inclusion of Women, Minorities and Children:}

- Sex/Gender: Distribution justified scientifically.

- Race/Ethnicity: Distribution justified scientifically.

- For NIH-Defined Phase III trials, Plans for valid design and analysis: Not applicable.

- Inclusion/Exclusion of Children under 18: Excluding ages <18; justified scientifically.

Vertebrate Animals:

Not Applicable (No Vertebrate Animals). 


\section{PROGRAM PROJECT AGGREGATE ROSTER \\ NATIONAL INSTITUTE ON AGING January 2017 Council Round}

THE ROSTER INCLUDES MEMBERS FROM MULTIPLE NIA P01 SPECIAL EMPHASIS PANELS OF THIS IRG:

\section{CHAIRPERSON(S)}

ANDERSON, ROZALYN M., PHD

ASSOCIATE PROFESSOR

DEPARTMENT OF MEDICINE

DIVISION OF GERIATRICS

UNIVERSITY OF WISCONSIN

MADISON, WI 53706

ASTHANA, SANJAY, MD

PROFESSOR AND HEAD

DEPARTMENT OF GERIATRICS AND

GERONTOLOGY

UNIVERSITY OF WISCONSIN SCHOOL OF

MEDICINE

MADISON, WI 53705

COX, DONALD C., PHD

PROFESSOR

DEPARTMENT OF ECONOMICS

BOSTON COLLEGE

CHESTNUT HILL, MA 02467

CRIBBS, DAVID HASTINGS, PHD

PROFESSOR AND ASSOCIATE DIRECTOR

DEPARTMENT OF NEUROLOGY

THE INSTITUTE FOR MEMORY

IMPAIRMENTS AND NEUROLOGICAL

DISORDERS

UNIVERSITY OF CALIFORNIA, IRVINE

IRVINE, CA 92697

DEKOSKY, STEVEN T., MD

PROFESSOR OF NEUROLOGY

INTEREIM EXECUTIVE DIRECTOR

MCKNIGHT BRAIN INSTITUTE

UNIVERSITY OF FLORIDA

GAINESVILLE, FL 32610
DOW, WILLIAM HATFIELD, PHD

HENRY J. KAISER PROFESSOR AND

DIRECTOR

CENTER ON THE ECONOMICS AND

DEMOGRAPHY OF AGING

SCHOOL OF PUBLIC HEALTH

UNIVERSITY OF CALIFORNIA, BERKELEY

BERKELEY, CA 94720

HO, VIVIAN, PHD

PROFESSOR

DEPARTMENT OF ECONOMICS

JAMES A. BAKER III INSTITUTE CHAIR IN

HEALTH ECONOMICS

INSTITUTE FOR PUBLIC POLICY

RICE UNIVERSITY

HOUSTON, TX 77251

KOHL, HAROLD WILLIS, PHD

PROFESSOR

DEPARTMENT OF KINESIOLOGY AND

HEALTH EDUCATION

UNIVERSITY OF TEXAS AT AUSTIN

AUSTIN, TX 78701

LANE, JULIA INGRID, PHD

SENIOR MANAGING ECONOMIST

AMERICAN INSTITUTES FOR RESEARCH

WASHINGTON, DC 20007

LOESER, RICHARD F., MD

PROFESSOR

DIVISION OF RHEUMATOLOGY

THURSTON ARTHRITIS RESEARCH

CENTER

UNIVERSITY OF NORTH CAROLINA

CHAPEL HILL, NC 27599

RECANZONE, GREGG HOWARD, PHD 
LACROIX, A

PROFESSOR

SECTION OF NEUROBIOLOGY,

PHYSIOLOGY AND BEHAVIOR CENTER FOR

NEUROSCIENCE

UNIVERSITY OF CALIFORNIA, DAVIS

DAVIS, CA 95618

ROBBINS, PAUL D., PHD

PROFESSOR

DEPARTMENT OF METABOLISM AND AGING

THE SCRIPPS RESEARCH INSTITUTE

JUPITER, FL 33458

TATAR, MARC, PHD

PROFESSOR

DEPARTMENT OF ECOLOGY AND

EVOLUTIONARY BIOLOGY

BROWN UNIVERSITY

PROVIDENCE, RI 02912

VIJG, JAN, PHD

PROFESSOR

DEPARTMENT OF GENETICS

ALBERT EINSTEIN COLLEGE OF MEDICINE BRONX, NY 10461

WOLOZIN, BENJAMIN L., PHD, MD

PROFESSOR

DEPARTMENTS OF PHARMACOLOGY AND

NEUROLGY

BOSTON UNIVERSITY SCHOOL OF

MEDICINE

BOSTON, MA 02118

ZAIDI, MONE, MBBS, PHD, MD

DIRECTOR

DIVISION OF ENDOCRINOLOGY

MOUNT SINAI SCHOOL OF MEDICINE

NEW YORK, NY 10029

\section{MEMBERS}

AGARWAL, SUDHA, PHD

PROFESSOR

DEPARTMENT OF ORTHOPEDICS

COLLEGE OF MEDICINE

OHIO STATE UNIVERSITY

COLUMBUS, OH 43210

ANDEL, ROSS, PHD

ASSOCIATE PROFESSOR

UNIVERSITY OF SOUTH FLORIDA
SCHOOL OF AGING STUDIES

TAMPA, FL 33620

ANTON, STEPHEN D., PHD

ASSOCIATE PROFESSOR

AGING AND GERIATRIC RESEARCH

UNIVERSITY OF FLORIDA

GAINESVILLE, FL 32611

ARANCIO, OTTAVIO, PHD, MD

ASSOCIATE PROFESSOR

DEPARTMENT OF PATHOLOGY

AND CELL BIOLOGY

COLUMBIA UNIVERSITY MEDICAL CENTER

NEW YORK, NY 10032

ARBEEV, KONSTANTIN G., PHD

DEPARTMENT OF SOCIOLOGY

DUKE UNIVERSITY

DURHAM, NC 27708

BANNASCH, DANIKA L., PHD, DVM MAXINE ADLER ENDOWED CHAIR DEPARTMENT OF POPULATION HEALTH AND REPRODUCTION SCHOOL OF VETERINARY MEDICINE UNIVERSITY OF CALIFORNIA DAVIS DAVIS, CA 95616

BARGER, STEVEN W., PHD PROFESSOR

REYNOLDS INSTITUTE ON AGING UNIVERSITY OF ARKANSAS FOR MEDICAL SCIENCES

LITTLE ROCK, AR 72205

BATTERMAN, STUART A., PHD PROFESSOR

DEPARTMENT OF ENVIORNMENTAL

HEALTH SCIENCES

SCHOOL OF PUBLIC HEALTH

UNIVERSITY OF MICHIGAN

ANN ARBOR, MI 48109-2029

BAUR, JOSEPH A., PHD

ASSISTANT PROFESSOR OF PHYSIOLOGY

DEPARTMENT OF PHYSIOLOGY

PERELMAN SCHOOL OF MEDICINE

UNIVERSITY OF PENNSYLVANIA

PHILADELPHIA, PA 19104

BERNARD, DANIEL J., PHD 
LACROIX, A

PROFESSOR

DEPARTMENT OF PHARMACOLOGY AND

THERAPEUTICS

MCGILL UNIVERSITY

MONTREAL, QC H3G 1 Y6

CANADA

BLACKER, DEBORAH L., MD, SCD

PROFESSOR

DEPARTMENT OF PSYCHIATRY

MASSACHUSETTS GENERAL HOSPITAL

CHARLESTOWN, MA 02129-2000

BLAU, DAVID M., PHD

PROFESSOR

DEPARTMENT OF ECONOMICS

THE OHIO STATE UNIVERSITY

COLUMBUS, OH 43210

BOND, DALE S., PHD

ASSOCIATE PROFESSOR

WEIGHT CONTROL AND DIABETES

RESEARCH CENTER

THE MIRIAM HOSPITAL

BROWN UNIVERSITY

PROVIDENCE, RI 02903

BUCKNER, RANDY L., PHD

PROFESSOR

DEPARTMENT OF PSYCHOLOGY

HARVARD UNIVERSITY

CAMBRIDGE, MA 02138

BUNDORF, MARY KATE, PHD

ASSOCIATE PROFESSOR

DEPARTMENT OF HEALTH RESEARCH AND

POLICY

STANFORD UNIVERSITY SCHOOL OF

MEDICINE

STANFORD, CA 94305

BROWN-BORG, HOLLY M., PHD

PROFESSOR

DEPARTMENT OF BASIC SCIENCES

SCHOOL OF MEDICINE AND HEALTH

SCIENCES

UNIVERSITY OF NORTH DAKOTA

GRAND FORKS, ND 58203

CALOF, ANNE LEIGHTON, PHD

PROFESSOR

DEPARTMENT OF ANATOMY AND
NEUROBIOLOGY

COLLEGE OF MEDICINE

UNIVERSITY OF CALIFORNIA, IRVINE

IRVINE, CA 92697

CHATTERJI, SOMNATH, MBBS, MD

WORLD HEALTH ORGANIZATION

HEALTH STATISTICS \& INFORMATICS

GENEVA, SWITZERLAND

CHEADLE, JACOB E., PHD

ASSOCIATE PROFESSOR

UNIVERSITY OF NEBRASKA LINCOLN

LINCOLN, NE 68512

CHI, GUANGQING, PHD

ASSOCIATE PROFESSOR

DEPARTMENT OF AGRICULTURAL

ECONOMICS, SOCIOLOGY AND EDUCATION

PENNSYLVANIA STATE UNIVERSITY

UNIVERSITY PARK, PA 16802

CHILDS, GWEN V., PHD

PROFESSOR AND CHAIR

DEPARTMENT OF NEUROBIOLOGY

AND DEVELOPMENTAL SCIENCES

UNIVERSITY OF ARKANSAS

LITTLE ROCK, AR 72205

CIRRITO, JOHN R., PHD

ASSOCIATE PROFESSOR

DEPARTMENT OF NEUROLOGY

WASHINGTON UNIVERSITY SCHOOL OF

MEDICINE

ST. LOUIS, MO 63110

CONNEELY, KAREN, PHD

ASSISTANT PROFESSOR

DEPARTMENT OF HUMAN GENETICS

EMORY UNIVERSITY SCHOOL OF MEDICINE

ATLANTA, GA 30322

CONOVER, CHERYL A., PHD

PROFESSOR

DEPARTMENT OF INTERNAL MEDICINE

MAYO CLINIC COLLEGE OF MEDICINE

ROCHESTER, MN 55905

CURRAN, SARA R., PHD

ASSOCIATE PROFESSOR

DANIEL J. EVANS SCHOOL OF PUBLIC

AFFAIRS 
LACROIX, A

UNIVERSITY OF WASHINGTON

SEATTLE, WA 98195

DAVIS, MICHAEL S., DVM, PHD

CHIEF OFFICER

CENTER FOR VETERINARY HEALTH

SCIENCES

OKLAHOMA STATE UNIVERSITY

STILLWATER, OK 74078

ELLIOTT, DAWN M., PHD

PROFESSOR AND CHAIR

DEPARTMENT OF BIOMEDICAL

ENGINEERING

UNIVERSITY OF DELAWARE

NEWARK, DE 19716

FISCHER, WOLFGANG H., PHD

SENIOR STAFF SCIENTIST

THE CLAYTON FOUNDATION

LABORATORIES FOR PEPTIDE BIOLOGY

THE SALK INSTITUTE

LA JOLLA, CA 92037

FERGUSON, SHAWN, PHD

ASSISTANT PROFESSOR

DEPARTMENT OF CELL BIOLOGY

YALE UNIVERISTY SCHOOL OF MEDICINE

NEW HAVEN, CT 06510

FRISINA, ROBERT D., PHD

PROFESSOR AND BME DIRECTOR

DEPARTMENT OF CHEMICAL

AND BIOMEDICAL ENGINEERING

UNIVERSITY OF SOUTH FLORIDA

TAMPA, FL 33620

GIBSON, GARY J., PHD

HEAD, SECTION OF CELL BIOLOGY

BONE AND JOINT CENTER

HENRY FORD HOSPITAL

DETROIT, MI 48202

GOLDRING, MARY B., PHD

PROFESSOR

CELL AND DEVELOPMENTAL BIOLOGY

WEILL CORNELL MEDICAL COLLEGE

NEW YORK, NY 10021

GRANHOLM-BENTLEY, ANN-CHARLOTTE

ESTHER, DDS, PHD

PROFESSOR AND DIRECTOR
KNOEBEL CENTER FOR THE STUDY OF

AGINGUNIVERSITY OF DENVER

DENVER, CO 80208

GUTMANN, MYRON P., PHD

DIRECTOR AND PROFESSOR OF HISTORY

UNIVERSITY OF COLORODO

1440 15TH STREE5T

BOULDER, CO 80309

HAMILTON, KARYN L., PHD

PROFESSOR

DEPARTMENT OF HEALTH AND EXERCISE

SCIENCE

COLORADO STATE UNIVERSITY

FORT COLLINS, CO 80523

JAMES, BRYAN DAVID, PHD

ASSISTANT PROFESSOR

RUSH ALZHEIMER'S DISEASE CENTER

CHICAGO, IL 60612

JASPER, HEINRICH, PHD

PROFESSOR

THE BUCK INSTITUTE FOR RESEARCH ON

AGING

NOVATO, CA 94945

JENNINGS, JULIA, PHD

ASSISTANT PROFESSOR

STATE UNIVERSITY OF NEW YORK AT

ALBANY

ALBANY, NY 12202

JOHNSON, DAVID K., PHD

ASSOCIATE PROFESSOR

DEPARTMENT OF PSYCHOLOGY

UNIVERSITY OF KANSAS

LAWRENCE, KS 66045

JOHNSON, MATTHEW WAYNE, PHD

ASSOCIATE PROFESSOR

DEPARTMENT OF PSYCHIATRY

AND BEHAVIORAL SCIENCES

JOHNS HOPKINS UNIVERSITY SCHOOL OF

MEDICINE

BALTIMORE, MD 21224

JONES, DAMON, PHD

ASSISTANT PROFESSOR

THE HARRIS SCHOOL OF PUBLIC POLICY

STUDIES 
LACROIX, A

UNIVERSITY OF CHICAGO

CHICAGO, IL 60637

KAKAR, SHAM S., PHD

PROFESSOR

DEPARTMENT OF MEDICINE

UNIVERSITY OF LOUISVILLE

LOUISVILLE, KY 40202

KANG, DAVID E., PHD

ASSOCIATE PROFESSOR

DEPARTMENT OF MOLECULAR MEDICINE

BYRD ALZHEIMER'S INSTITUTE

UNIVERSITY OF SOUTH FLORIDA

TAMPA, FL 33613

KASAKOFF, ALICE BEE, PHD

DEPARTMENT OF ANTHROPOLOGY

UNIVERSITY OF SOUTH CAROLINA AT

COLUMBIA

COLUMBIA, SC 29208

KAUWE, JOHN SAI KEONG, PHD

ASSOCIATE PROFESSOR

DEPARTMENTS OF BIOLOGY AND

NEUROSCIENCE

BRIGHAM YOUNG UNIVERSITY

PROVO, UT 84602

KENNEDY, BRIAN K., PHD

PRESIDENT, CEO AND PROFESSOR

BUCK INSTITUTE FOR RESEARCH ON

AGING

NOVATO, CA 94945

KETCHAM, JONATHAN DAVID, PHD

ASSOCIATE PROFESSOR

W.P. CAREY SCHOOL OF BUSINESS

DEPARTMENT OF MARKETING

ARIZONA STATE UNIVERSITY

TEMPE, AZ 85287

KITSIS, RICHARD N., MD

PROFESSOR

DORROS CHAIR IN CARDIOVASCULAR

DISEASE

DIRECTOR, WILF FAMILY

CARDIOVASCULAR RESEARCH INSTITUTE

ALBERT EINSTEIN COLLEGE OF MEDICINE

BRONX, NY 10461

KOHLER, HANS-PETER, PHD
PROFESSOR

DEPARTMENT OF SOCIOLOGY

UNIVERSITY OF PENNSYLVANIA

PHILADELPHIA, PA 19104

KONDRATOV, ROMAN V., PHD

ASSOCIATE PROFESSOR

DEPARTMENT OF BIOLOGICAL,

GEOLOGICAL, AND ENVIRONMENTAL

SCIENCES

CLEVELAND STATE UNIVERSITY

CLEVELAND, OH 44115

KRAMER, JOEL H., PSYD

PROFESSOR

DEPARTMENT OF NEUROLOGY

UNIVERSITY OF CALIFORNIA, SAN

FRANCISCO

SAN FRANCISCO, CA 94158

KRYSCIO, RICHARD J., PHD

PROFESSOR AND CHAIR

DEPARTMENT OF STATISTICS AND

BIOSTATISTICS

UNIVERSITY OF KENTUCKY

LEXINGTON, KY 40536

LA SPADA, ALBERT R., MD, PHD

PROFESSOR

DEPARTMENTS OF PEDIATRICS, CELLULAR

AND MOLECULAR MEDICINE AND

NEUROSCIENCES

UNIVERSITY OF CALIFORNIA AT SAN

DIEGO

LA JOLLA, CA 92093

LEFLER, LEANNE L., PHD, BSN

ASSOCIATE PROFESSOR

DEPARTMENT OF NURSING

COLLEGE OF NURSING

UNIVERSITY OF ARKANSAS FOR MEDICAL

SCIENCES

LITTLE ROCK, AR 72205

LEGER, PIERRE

ASSOCIATE PROFESSOR

DIVISION OF HEALTH POLICY AND

ADMINISTRATION

SCHOOL OF PUBLIC HEALTH

UNIVERSITY OF ILLINOIS AT CHICAGO

CHICAGO, IL 60612 
LACROIX, A

LOSASSO, ANTHONY T., PHD

PROFESSOR AND SENIOR RESEARCH

SCIENTIST

HEALTH POLICY AND ADMINISTRATION

UNIVERSITY OF ILLINOIS AT CHICAGO

CHICAGO, IL 60612

MAO, ZIXU, MD, PHD

PROFESSOR

DEPARTMENT OF PHARMACOLOGY AND

NEUROLOGY

EMORY UNIVERSITY SCHOOL OF MEDICINE

ATLANTA, GA 30322

MARTIN, GEORGE M., MD

PROFESSOR

DEPARTMENT OF PATHOLOGY

UNIVERSITY OF WASHINGTON

SEATTLE, WA 98195

MCCARTER, ROGER JOHN, PHD

PROFESSOR

DEPARTMENT OF PHYSIOLOGY

UNIVERSITY OF TEXAS HEALTH

SCIENCE CENTER

SAN ANTONIO, TX 78284

MEDVENE, LOUIS J., PHD

PROFESSOR

DEPARTMENT OF PSYCHOLOGY

WICHITA STATE UNIVERSITY

WICHITA, KS 67260

MOODY, JAMES, PHD

PROFESSOR

DEPARTMENT OF SOCIOLOGY

DUKE UNIVERSITY

DURHAM, NC 27708

MURPHY, COLEEN TARA, PHD

PROFESSOR

DEPARTMENT OF MOLECULAR BIOLOGY

AND GENOMICS

PRINCETON UNIVERSITY

PRINCETON, NJ 08544

NAVARATNAM, DHASAKUMAR S., MD, PHD ASSOCIATE PROFESSOR

DEPARTMENT OF NEUROLOGY AND

NEUROBIOLOGY

YALE UNIVERSITY

NEW HAVEN, CT 06510
NOSAL, KATHLEEN, PHD

ASSISTANT PROFESSOR

DEPARTMENT OF ECONOMICS

UNIVERSITY OF MANNHEIM

MANNHEIM 68161

GERMANY

OLSEN, RANDALL J., PHD

PROFESSOR

DEPARTMENT OF ECONOMICS

THE OHIO STATE UNIVERSITY

COLUMBUS, OH 43221

PAGE, RODNEY LEE, DVM

DIRECTOR

DEPARTMENT OF CLINICAL SCIENCES

COLORADO STATE UNIVERSITY

DENVER, CO 80208

PETERS-LIBEU, CLARE A., PHD

STAFF SCIENTIST

BUCK INSTITUTE FOR RESEARCH ON

AGING

NOVATO, CA 94945

PEELLE, JONATHAN E., PHD

ASSISTANT PROFESSOR

WASHINGTON UNIVERSITY

SAINT LUIS, MO 63110

SALVY, SARAH-JEANNE, PHD

ASSOCIATE PROFESSOR

CHAN DIVISION OF OCCUPATIONAL

SCIENCE AND OCCUPATIONAL THERAPY

UNIVERSITY OF SOUTHERN CALIFORNIA

LOS ANGELES, CA 90089

SCHAFFER, DAVID V., PHD

PROFESSOR

DEPARTMENT OF CHEMICAL ENGINEERING

UNIVERSITY OF CALIFORNIA, BERKELEY

BERKELEY, CA 94720

SCHNEIDER, JULIE A., MD

PROFESSOR AND ASSOCIATE DIRECTOR

DEPARTMENT OF PATHOLOGY

RUSH ALZHEIMER'S DISEASE CENTER

RUSH UNIVERSITY MEDICAL CENTER

CHICAGO, IL 60612

SELL, CHRISTIAN, PHD 
LACROIX, A

ASSOCIATE PROFESSOR

DEPARTMENT OF PATHOLOGY

COLLEGE OF MEDICINE

DREXEL UNIVERSITY

PHILADELPHIA, PA 19102

SHELINE, YVETTE I., MD

PROFESSOR AND DIRECTOR

DEPARTMENT OF PSYCHIATRY

CENTER FOR THE NEUROMODULATION IN DEPRESSION AND STRESS

UNIVERSITY OF PENNSYLVANIA SCHOOL

OF MEDICINE

PHILADELPHIA, PA 19104

SIMMONS, DWAYNE D., PHD

PROFESSOR AND DIRECTOR OF

MARC/BRIDGES

DEPARTMENT OF INTEGRATIVE BIOLOGY

AND PHYSIOLOGY

UNIVERSITY OF CALIFORNIA, LOS

ANGELES

LOS ANGELES, CA 90095

SUBRAMANIAN, SUJHA, PHD

SENIOR HEALTH ECONOMIST

DIVISION OF HEALTH ECONOMICS

RESEARCH

RESEARCH TRIANGLE INSTITUTE

WALTHAM, MA 02452-8414

STAFFORD, FRANK PETER, PHD

PROFESSOR OF ECONOMICS

DEPARTMENT OF ECONOMICS

UNIVERSITY OF MICHIGAN

ANN ARBOR, MI 48106

SWARTZ, ANN M., PHD

PROFESSOR AND CHAIR

DEPARTMENT OF KINESIOLOGY

EXERCISE SCIENCE \& HEALTH

PROMOTION

COLLEGE OF HEALTH SCIENCES

UNIVERSITY OF WISCONSIN-MILWAUKEE

MILWAUKEE, WI 53201-0413

TEMPLE, SALLY, PHD

PROFESSOR

NEW YORK NEURAL STEM INSTITUTE

RENSSELAER, NY 12144

THOMPSON, WINSTON E., PHD
PROFESSOR

DEPARTMENT OF PHYSIOLOGY

MOREHOUSE SCHOOL OF MEDICINE

ATLANTA, GA 30310

THYFAULT, JOHN P., PHD

ASSOCIATE PROFESSOR

DEPARTMENT OF MOLECULAR

INTEGRATIVE PHYSIOLOGY

UNIVERSITY OF KANSAS MEDICAL CENTER

KANSAS CITY, KS 66160

TRAVISON, THOMAS GLENN, PHD

SENIOR SCIENTIST AND DIRECTOR

INSTITUTE FOR AGING RESEARCH

DIVISION OF GERONTOLOGY

HARVARD MEDICAL SCHOOL

BOSTON, MA 02131

TRUSHINA, EUGENIA, PHD

ASSOCIATE PROFESSOR

DEPARTMENT OF NEUROLOGY AND

PHARMACOLOGY

MAYO CLINIC COLLEGE OF MEDICINE

ROCHESTER, MN 55905

VARELA, MAURICIO, PHD

ASSISTANT PROFESSOR

DEPARTMENT OF ECONOMICS

UNIVERSITY OF ARIZONA

TUCSON, AZ 85721

VILLEDA, SAUL A., PHD

ASSISTANT PROFESSOR

UNIVERSITY OF CALIFORNIA SAN

FRANCISCO

SAN FRANCISCO, CA 94143

WAIDMANN, TIMOTHY A., PHD

SENIOR RESEARCH ASSOCIATE

HEALTH POLICY CENTER

URBAN INSTITUTE

WASHINGTON, DC 20037

WALKER, WILLIAM H., PHD

ASSOCIATE PROFESSOR

DEPARTMENT OF CELL BIOLOGY AND

PHYSIOLOGY

UNIVERSITY OF PITTSBURGH

PITTSBURGH, PA 15261

WANG, HONGMEI, PHD 
LACROIX, A

UNIVERSITY OF NEBRASKA MEDICAL

CENTER

OMAHA, NE 68198

WELSH-BOHMER, KATHLEEN ANNE, PHD

PROFESSOR AND DIRECTOR

DEPARTMENTS OF PSYCHOLOGY AND

NEUROLOGY

ALZHEIMER'S DISEASE CENTER

DUKE UNIVERSITY

DURHAM, NC 27705

WEINSTEIN, MAXINE A., PHD

DISTINGUISHED PROFESSOR

GRADUATE SCHOOL OF ARTS AND

SCIENCES

CENTER FOR POPULATION AND HEALTH

GEORGETOWN UNIVERSITY

WASHINGTON, DC 20057

WESTENDORF, JENNIFER J., PHD

MARGARET AMINI PROFESSOR

DEPARTMENT OF ORTHOPEDICS,

BIOCHEMISTRY AND MOLECULAR BIOLOGY

MAYO CLINIC

ROCHESTER, MN 55905

WILKER, ELISSA, SCD

ASSISTANT PROFESSOR OF MEDICINE

DEPARTMENT OF MEDICINE AND

EPEDEMIOLOGY

HARVARD MEDICAL SCHOOL

BOSTON, MA 02215

WINGFIELD, ARTHUR, PHD

PROFESSOR

DEPARTMENT OF PSYCHOLOGY AND

NEUROSCIENCE

DIRECTOR, VOLEN NATIONAL CENTER

FOR COMPLEX SYSTEMS

BRANDEIS UNIVERSITY

WALTHAM, MA 02454

YUE, ZHENYU, PHD

PROFESSOR

DEPARTMENT OF NEUROLOGY AND

NEUROSCIENCE

ICAHN SCHOOL OF MEDICINE AT MOUNT

SINAI

NEW YORK, NY 10029

ZAGHENI, EMILIO, PHD
ASSISTANT PROFESSOR

DEPARTMENT OF SOCIOLOGY

UNIVERSITY OF WASHINGTON

SEATTLE, WA 98195

ZHANG, MIN, PHD, MD

ASSOCIATE PROFESSOR

DEPARTMENT OF STATISTICS

PURDUE UNIVERSITY

WEST LAFAYETTE, IN 47907

ZHANG, QI, PHD

ASSISTANT PROFESSOR

DEPARTMENT OF PHARMACOLOGY

VANDERBILT UNIVERSITY MEDICAL

CENTER

NASHVILLE, TN 37232

ZHENG, HUI, PHD

PROFESSOR AND DIRECTOR

HUFFINGTON CENTER ON AGING

BAYLOR COLLEGE OF MEDICINE

HOUSTON, TX 77030

\section{SCIENTIFIC REVIEW OFFICER}

BISSONETTE, GREG, PHD

SCIENTIFIC REVIEW BRANCH

NATIONAL INSTITUTE ON AGING

NATIONAL INSTITUTES OF HEALTH

BETHESDA, MD 20892

FIRTH, KIMBERLY, PHD

SCIENTIFIC REVIEW BRANCH

NATIONAL INSTITUTE ON AGING

NATIONAL INSTITUTES OF HEALTH

BETHESDA, MD 20892

GRIMALDI, MAURIZIO, MD, PHD

SCIENTIFIC REVIEW OFFICER

NATIONAL INSTITUTE ON AGING

NATIONAL INSTITUTES OF HEALTH

BETHESDA, MD 20892

MARKOWSKA, ALICJA L., PHD, DSC

SCIENTIFIC REVIEW BRANCH

NATIONAL INSTITUTE ON AGING

NATIONAL INSTITUTES OF HEALTH

BETHESDA, MD 20982

MIKHAIL, ISIS S., MD, MPH, DRPH

SCIENTIFIC REVIEW BRANCH 
LACROIX, A

NATIONAL INSTITUTE ON AGING NATIONAL INSTITUTES OF HEALTH BETHESDA, MD 20892

MOTEN, CARMEN, PHD, MPH SCIENTIFIC REVIEW BRANCH NATIONAL INSTITUTE ON AGING NATIONAL INSTITUTES OF HEALTH BETHESDA, MD 20892

NAKHAI, BITA, PHD SCIENTIFIC REVIEW BRANCH NATIONAL INSTITUTE ON AGING NATIONAL INSTITUTES OF HEALTH BETHESDA, MD 20814

PARSADANIAN, ALEXANDER, PHD SCIENTIFIC REVIEW OFFICER SCIENTIFIC REVIEW BRANCH NATIONAL INSTITUTE ON AGING NATIONAL INSTITUTES OF HEALTH BETHESDA, MD 20892

PRASAD, NIJAGUNA, MS, PHD SCIENTIFIC REVIEW OFFICER SCIENTIFIC REVIEW BRANCH NATIONAL INSTITUTE ON AGING NATIONAL INSTITUTES OF HEALTH BETHESDA, MD 20892

\section{EXTRAMURAL SUPPORT ASSISTANT}

GLENN, JENNIFER N

EXTRAMURAL SUPPORT ASSISTANT SCIENTIFIC REVIEW BRANCH NATIONAL INSTITUTE ON AGING NATIONAL INSTITUTES OF HEALTH BETHESDA, MD 20894

WILSON, SHAYLA K EXTRAMURAL SUPPORT ASSISTANT SCIENTIFIC REVIEW BRANCH NATIONAL INSTITUTE ON AGING NATIONAL INSTITUTE OF HEALTH BETHESDA, MD 20892

WOODEN, EZELLE III EXTRAMURAL SUPPORT ASSISTANT SCIENTIFIC REVIEW BRANCH NATIONAL INSTITUTE ON AGING NATIONAL INSTITUTES OF HEALTH BETHESDA, MD 20892

\section{PROGRAM REPRESENTATIVE}

BHATTACHARYYA, PARTHA, PHD

PROGRAM DIRECTOR

DIVISION OF BEHAVIORAL AND SOCIAL RESEARCH

NATIONAL INSTITUTE ON AGING

NATIONAL INSTITUTES OF HEALTH

BETHESDA, MD 20892

FRIDELL, YIH-WOEI

DIVISION OF AGING BIOLOGY

NATIONAL INSTITUTE ON AGING

NATIONAL INSTITUTES OF HEALTH

BETHESDA, MD 20892

FULDNER, REBECCA A., PHD

HEALTH SCIENCE ADMINISTRATOR

BIOLOGY OF AGING PROGRAM

NATIONAL INSTITUTE ON AGING

BETHESDA, MD 20814

HSIAO, JOHN, MD

HEALTH SCIENTIST ADMINISTRATOR

DIVISION OF NEUROSCIENCE

NATIONAL INSTITUTE ON AGING

NATIONAL INSTITUTES OF HEALTH

BETHESDA, MD 20892

JOSEPH, LYNDON J O, PHD

ROMASHKAN, SERGEI, MD, PHD

BRANCH CHIEF

HEALTH SCIENTIST ADMINISTRATOR

GERIATRICS AND CLINICAL

GERONTOLOGY

NATIONAL INSTITUTE ON AGING

NATIONAL INSTITUTES OF HEALTH

BETHESDA, MD 20892

KOHANSKI, RONALD A., PHD

DEPUTY DIRECTOR

BIOLOGY OF AGING PROGRAM

NATIONAL INSTITUTE ON AGING

BETHESDA, MD 20814

PATMIOS, GEORGEANNE E.,

PROGRAM OFFICER

DIVISION OF BEHAVIORAL AND SOCIAL

RESEARCH

NATIONAL INSTITUTE ON AGING

NATIONAL INSTITUTES OF HEALTH 
BETHESDA, MD 20892

ROMASHKAN, SERGEI, MD, PHD BRANCH CHIEF

HEALTH SCIENCE ADMINISTRATOR

DIVISION OF GERIATRICS AND CLINICAL

GERONTOLOGY

NATIONAL INSTITUTE ON AGING

NATIONAL INSTITUTES OF HEALTH

BETHESDA, MD 20893

WILLIAMS, JOHN PHILIP, PHD HEALTH SCIENCE ADMINISTRATOR

NATIONAL INSTITUTE OF HEALTH

NATIONAL INSTITUTE OF AGING

DIVISION OF AGING BIOLOGY

BETHESDA, MD 20892
WISE, BRADLEY C., PHD

CHIEF, HEALTH SCIENTIST

ADMINISTRATOR

DIVISION OF NEUROSCIENCE

NATIONAL INSTITUTE ON AGING

NATIONAL INSTITUTES OF HEALTH

BETHESDA, MD 20892

YANG, AUSTIN JYAN-YU

HEALTH SCIENTIST ADMINISTRATOR

DIVISION OF NEUROSCIENCE

NATIONAL INSTITUTE ON AGING

BETHESDA, MD 20892

Footnotes for 1 P01 AG052352-01A1; PI Name: LACROIX, ANDREA Z.

$\mathrm{NIH}$ has modified its policy regarding the receipt of resubmissions (amended applications). See Guide Notice NOT-OD-14-074 at http://grants.nih.gov/grants/guide/notice-files/NOT-OD14-074.html. The impact/priority score is calculated after discussion of an application by averaging the overall scores (1-9) given by all voting reviewers on the committee and multiplying by 10 . The criterion scores are submitted prior to the meeting by the individual reviewers assigned to an application, and are not discussed specifically at the review meeting or calculated into the overall impact score. Some applications also receive a percentile ranking. For details on the review process, see http://grants.nih.gov/grants/peer_review_process.htm\#scoring. 


\title{
MEETING ROSTER
}

National Institute on Aging Special Emphasis Panel

\author{
NATIONAL INSTITUTE ON AGING \\ Second Stage P01 Review \\ ZAG1 ZIJ-7 (J1) \\ $11 / 21 / 2016$
}

\section{CHAIRPERSON(S)}

MELTZER, DAVID O, MD, PHD

PROFESSOR

DEPARTMENT OF MEDICINE

CHIEF, SECTION OF HOSPITAL MEDICINE

DIRECTOR, CENTER FOR HEALTH AND THE SOCIAL SCS.

UNIVERSITY OF CHICAGO

CHICAGO, IL 60637

\section{MEMBERS}

BICKFORD, PAULA C, PHD

DISTINGUISHED USF HEALTH PROFESSOR

DEPARTMENT OF NEUROSURGERY

AND BRAIN REPAIR

USF MORSANI COM

MDC-78

TAMPA, FL 33612

CAMPISI, JUDITH, PHD

PROFESSOR

BUCK INSTITUTE FOR AGE RESEARCH

LABORATORY OF CELLULAR AND

MOLECULAR BIOLOGY OF AGING

NOVATO, CA 94945

CARSTENSEN, LAURA L, PHD

PROFESSOR

THE FAIRLEIGH S. DICKINSON JR. PROFESSOR IN

PUBLIC POLICY

DIRECTOR, STANFORD CENTER ON LONGEVITY

STANFORD UNIVERSITY

STANFORD, CA 94305

DE LEON, MONY J., EDD

PROFESSOR OF PSYCHIATRY

DEPARTMENT OF PSYCHIATRY

SCHOOL OF MEDICINE

NEW YORK UNIVERSITY

NEW YORK, NY 10016

KRITCHEVSKY, STEPHEN B., PHD

DIRECTOR

STRICHT CENTER ON AGING

DEPARTMENT OF INTERNAL MEDICINE

WAKE FOREST UNIVERSITY

WINSTON-SALEM, NC 27157
KUCHEL, GEORGE A, MD

DIRECTOR, UCONN CENTER ON AGING

DEPARTMENT OF MEDICINE

CENTER OF AGING

UNIVERSITY OF CONNECTICUT HEALTH CENTER

FARMINGTON, CT 06030

RICHARDSON, ARLAN G., PHD

PROFESSOR

UNIVERSITY OF OKLAHOMA

ROCA/GERIATRIC MEDICINE

OKLAHOMA CITY, OK 73104

ROSENE, DOUGLAS L, PHD

PROFESSOR

DEPARTMENT OF ANTATOMY AND NEUROBIOLGY BOSTON UNIVERSITY SCHOOL OF MEDICINE

BOSTON, MA 02118

SIEBER, FREDERICK E, MD

PROFESSOR

DEPARTMENT OF ANESTHESIOLOGYI

CRITICAL CARE MEDICINE

JOHNS HOPKINS UNIVERSITY

BALTIMORE, MD 21224

SMITH, JAMES PATRICK, PHD

NEPHROLOGIST AND MEDICAL OFFICER

RAND CORPORATION

DEPT OF LABOR AND POPULATION

SANTA MONICA, CA 90407-2138

VAN ELDIK, LINDA J, PHD

PROFESSOR AND DIRECTOR

SANDERS-BROWN CENTER ON AGING

UNIVERSITY OF KENTUCKY

LEXINGTON, KY 40536

\section{SCIENTIFIC REVIEW OFFICER}

VEMURI, RAMESH, PHD

CHIEF, SCIENTIFIC REVIEW BRANCH

NATIONAL INSTITUTE ON AGING

NATIONAL INSTITUTES OF HEALTH

BETHESDA, MD 20892 
EXTRAMURAL SUPPORT ASSISTANT

WILSON, SHAYLA K

EXTRAMURAL SUPPORT ASSISTANT

NATIONAL INSTITUTE ON AGING

NATIONAL INSTITUTE OF HEALTH

BETHESDA, MD 20892

Consultants are required to absent themselves from the room during the review of any application if their presence would constitute or appear to constitute a conflict of interest. 